\title{
Balancing Accountability and Trust: University reforms in the Nordic Countries
}

\author{
Hanne Foss Hansen (1)*, Lars Geschwind (2), Jussi Kivistö (3), Elias Pekkola (3), Rómulo \\ Pinheiro (4) and Kirsi Pulkkinen (5) \\ 1 Department of Political Science, University of Copenhagen, Denmark \\ 2 KTH Royal Institute of Technology, Stockholm, Sweden \\ 3 Faculty of Management, University of Tampere, Finland \\ 4 Department of Political Science and Management, University of Agder, Norway \\ 5 Faculty of Social Sciences, University of Helsinki and University of Lapland, Finland \\ *Corresponding author. Email: hfh@ifs.ku.dk
}

\begin{abstract}
This paper investigates the accountability mechanisms introduced in the universities in the Nordic countries by building on a typology of accountability types. By utilizing survey data, it analyses how academics experience the changes in accountability mechanisms, and how they perceive the impact of these changes on their performance. The analysis shows that especially political/bureaucratic and managerial accountability demands have been strengthened. This development has fostered debates on how to measure academic performance. Some academics, more in Denmark than in the other countries, have experienced the development as a sign of mistrust.
\end{abstract}

Keywords: Accountability, trust, universities, Nordic countries, performance management, policy reforms, academic perceptions 


\section{Introduction}

In recent decades, the quest for stronger accountability has been a driver of both public-sector reforms in general (Christensen and Lægreid 2017) and university reforms more specifically. A privileged focus has been given to performance aspects of accountability such as excellence, quality, goal attainment and effectiveness (Fägerlind \& Strömqvist 2004; Gornitzka et al. 2004). In addition to performance development and documentation, public universities, in the Nordic countries and elsewhere, are increasingly expected to respond adequately to the needs of various external stakeholder groups as well as to document their impact on societal development (Jongbloed et al. 2008; Neave 2002).

The quest for stronger accountability may have several explanations. Reforms aiming at strengthening accountability mechanisms may reflect a political rationality anchored in distrust in universities. Reforms may also reflect attempts to transform university cultures and values and thereby change their actions. However, accountability reforms may also be more symbolic, reflecting modern and international trends in public governance but not (in the short run) aiming at changing the behaviour of universities. In our empirical analysis, we investigate this 'why' question only to a limited extent. Instead, our analysis focuses on the content of accountability reforms and on how university academics experience these reforms.

One of the main issues in the university sector is the relation between the dramatic changes in terms of accountability demands, governance, management, leadership and organising, on the one hand, and trust, on the other (Ramirez 2010; Stensaker \& Harvey 2011). Societal distrust of universities, and managerial distrust within universities, may be considered independent variables, and as such, as mentioned above, they can be seen as reasons to strengthen accountability demands. However, as Olsen (2017: 520) has underlined, distrust may also be considered a dependent variable: 'accountability is, however, costly in terms of time, energy, and resources and excessive monitoring damages trust relations'.

To contribute to ongoing academic and policy discussions, the aim of this article is to shed light on aspects of and linkages between governance, accountability and trust in universities. We analyse data collected from four Nordic countries: Denmark, Finland, Norway and Sweden. In doing so, we particularly aim to address the lack of previous comparative research on the contents of recent management reforms and their impacts on accountability mechanisms across the Nordic higher education systems. More specifically, this article addresses the following research questions: (1) What types of accountability mechanisms have been introduced in university reforms in the Nordic countries? (2) How do academics experience accountability demands? (3) How do academics describe their impact on performance?

We approach these questions by looking at both the formal understanding and perceptions of academics regarding accountability. Traditions of collegiality, meritocracy and academic competition interact with demands of accountability and trust. We discuss whether and how there have been changes in practices and perceptions related to accountability over the last decade. We aim to shed light on how and to what extent recent reforms have influenced the use of accountability measures and perceptions of trust. The intention is thus to appraise academics' perceptions from the perspective of accountability regimes, not to compare perceptions with the overall performance of the research systems. Our primary focus is the last decade, but as reforms have taken place at different points of time in the four countries, the time horizon referred to is in some cases longer.

The article is structured in five sections. Section 2 presents the conceptual framework for the analysis and elaborates on the methodological approach. Section 3 sketches out the changes in accountability mechanisms introduced in university reforms in the last decade. Section 4 presents the second part of the analysis, focusing on how academics experience the consequences for academic work. Finally, section 5 pulls together the key findings and implications of our analysis.

\section{Conceptual framework, expectations and method}

As recently suggested by Huisman (2018), we use conceptualisations from public administration literature to analyse accountability dynamics in universities. The concept of accountability is characterised by ambiguity. Often, the concept is used in a broad sense, making it difficult to maintain clear distinctions between related concepts such as transparency, responsiveness, responsibility and answerability (Bovens 2007: 449; Dubnick 2014: 26). For analytical reasons, a more precise definition is needed. Here, Bovens' definition of accountability as a social relation is used: 'Accountability is a relationship between an actor and a forum, in which the actor has 
an obligation to explain and to justify his or her conduct, the forum can pose questions and pass judgment, and the actor may face consequences' (Bovens 2007: 450).

In our context, the actors required to answer to the forum may be individual academics, groups of academics (research groups, sections, departments, centres and faculties) or the university as an organisation. In the literature on accountability, many types of accountability and accountability forums have been discussed (Bovens 2007; Byrkeflot et al. 2013; Bovens, Schilleman, \& Goodin 2014). Due to our focus on how academics in universities experience the impact on performance, we focus on the following important types of forums to which the actors are accountable: political/bureaucratic forums, managerial forums and professional forums (peers). ${ }^{1}$ Table 1 sums up the characteristics of the accountability types included in the analysis and how they relate to different theoretical perspectives.

Table 1: Accountability types

\begin{tabular}{|c|c|c|c|c|}
\hline $\begin{array}{l}\text { Characteristics } \\
\text { of: } \\
\text { Accountability } \\
\text { type: }\end{array}$ & Forum actors & Relationship & $\begin{array}{l}\text { Organisational } \\
\text { context }\end{array}$ & Theoretical perspectives \\
\hline $\begin{array}{l}\text { Political/ } \\
\text { bureaucratic }\end{array}$ & $\begin{array}{l}\text { Government, } \\
\text { ministries, } \\
\text { agencies }\end{array}$ & Hierarchical & External & $\begin{array}{l}\text { Principal-agent theory: information } \\
\text { asymmetry, } \\
\text { delegation, goal conflicts etc. } \\
\text { (see Gailmard 2014) }\end{array}$ \\
\hline Managerial & $\begin{array}{l}\text { University } \\
\text { management }\end{array}$ & Hierarchical & Internal & $\begin{array}{l}\text { New public management: leadership, } \\
\text { explicit performance goals, competition } \\
\text { (Hood 1991; Christensen \& Lægreid 2011) }\end{array}$ \\
\hline Professional & Peers & $\begin{array}{l}\text { Network- } \\
\text { based }\end{array}$ & $\begin{array}{l}\text { Internal and } \\
\text { external }\end{array}$ & $\begin{array}{l}\text { Sociology of professions (Abbott 1988) } \\
\text { and normative isomorphism (Powell \& } \\
\text { DiMaggio 1991): codes of conduct, value } \\
\text { convergence }\end{array}$ \\
\hline
\end{tabular}

Whereas political/bureaucratic as well as managerial accountability relationships are hierarchical, professional relationships are network based. Political/bureaucratic accountability relates to principal-agent theory. In this perspective, accountability systems aim at forcing agents to deliver on the goals of the principals due to the existence of information asymmetry, delegation and conflicting goals. Managerial accountability relates to new public management. In this perspective, accountability systems aim at monitoring output and results in order to ensure that those answerable for carrying out tasks, here the academics, deliver on the performance criteria laid down by managers. Further, in this perspective, managerial performance criteria are laid down to enable organisations to compete on the market. Professional accountability relates to the sociology of professions. In this perspective, accountability systems aim at ensuring that actors adapt to professional codes of conduct.

In the university sector, we expect to find all these types of accountability relationships. The importance of the different types and the couplings between them may vary across time and countries. At the national level, political/bureaucratic accountability systems may be used to try to align universities with political agendas. At organisational levels, managerial accountability systems may be used by university managers to try to align the staff with university strategies. In professional networks, professional accountability systems may be used to try to uphold professional norms. Different accountability systems may be aligned or conflictual. For example, managers may align monitoring systems with political/bureaucratic accountability demands, but these may conflict with professional norms according to which professionals do not consider political/bureaucratic and managerial accountability systems meaningful.

In addition to the accountability types mentioned above, social accountability, defined as accountability relations with stakeholders and especially user groups, may be expected in universities. These are briefly touched upon in the country reform analyses, but as we have no data on how academics experience such

\footnotetext{
${ }^{1}$ We have chosen not to include democratic accountability, which refers to the relationship between political leaders, the parliament, voters and elected bodies of citizens and customers; financial accountability, which involves auditors; or legal accountability, which is related to the courts. These forms of accountability are only distantly related to university academics. 
relationships, they are not included in the table above.

Accountability relations are often, but not exclusively, linked to funding or resource dependencies (Pfeffer \& Salancik 2003). These may take different forms. Demands for performance data may be linked to governmental funding streams and thus belong to the political/bureaucratic accountability type. But they may also be linked to strategic internal university funding and thus belong to the managerial type. Further, they may be linked to research council funding and hence belong to the professional accountability type, or they may be linked to external funding from stakeholders, including consultancy work, and thus belong to the social accountability type.

In the first part of the analysis, which focuses on reforms, we expect to find strengthened external political/bureaucratic accountability mechanisms due to the growth of the university sector and the increased focus on economic efficiency in the wake of the financial crisis initiated in 2008. In addition, we expect to find strengthened internal managerial accountability mechanisms, as external political/bureaucratic accountability demands have to some extent been implemented at various organisational levels in universities, a process enabled by management reforms. Further, we expect to find that professional accountability faces challenges, although it continues to be highly appreciated by academics. In the second part of the analysis, which focuses on how academics experience and value accountability mechanisms, we expect to uncover tensions between accountability demands and critical viewpoints on impacts.

Methodologically, we approach the analyses with a combination of documentary material and survey data. Survey data were collected in Denmark, Finland, Norway and Sweden from the fall of 2015 to the spring of 2016. The target population of the survey was senior university academics (European career stages IV and III) who do not hold official managerial positions (e.g. heads of department, heads of centres) in four Nordic countries, namely Denmark, Sweden, Finland and Norway. The sample used in this article $(n=2923)$ represents well the senior academics working in these countries by institution, discipline, gender and title. The overall response rate in the survey varied from country to country between $20 \%$ and $25 \%$. The sampling was performed distinctly in respective countries. The descriptive data are visualised in Table 2.

Table 2. Survey sample

\begin{tabular}{|l|c|c|c|c|}
\hline & Denmark & Finland & Norway & Sweden \\
\hline $\mathrm{n}$ & 1,330 & 673 & 726 & 291 \\
\hline Title & & & & \\
\hline Professor & $29 \%$ & $39 \%$ & $47 \%$ & $39 \%$ \\
\hline Associate professor & $71 \%$ & $61 \%$ & $55 \%$ & $61 \%$ \\
\hline Position & & & & \\
\hline Permanent & $90 \%$ & $64 \%$ & $79 \%$ & $91 \%$ \\
\hline
\end{tabular}

The statistical analysis is performed by comparing means. The data have some limitations in terms of conducting one way analysis of variance. Firstly, the country samples differ from each other, especially in size. Because the Denmark sample is large compared to that of other countries, and especially that of Sweden, the variances of the samples are not equal. In addition, the variables used are Likert-scale statements, and consequently, the use of parametric tests can be considered inappropriate. Thus, all statistical analysis are performed using nonparametric tests (the Kruskall-Wallis $H$ test and, for post hoc tests, Dunn-Bonferroni tests).

\section{Reforms and implementation of changes in accountability mechanism: Country comparison}

In all the Nordic countries, accountability demands have been intensified and new types of accountability mechanisms have been introduced in the last decade. Below, we briefly present the most important changes at the national reform level in each of the countries we discuss.

\subsection{Denmark}

In Denmark, reforms and strong accountability demands are part of daily university life. Looking back, the most important reforms related to governance and accountability have been the introduction of contract steering in 2000 , the governance reform in 2003, the merger reform in 2007 and the introduction of still more mechanisms for performance-based resource allocation. This development can be traced back to 2001, when the Research 
Commission set a policy agenda including the need to increase the resources for public-sector research and to strengthen accountability mechanisms (Aagaard 2012). However, since 2016 there has been a policy shift towards introducing cutbacks.

In the growth period, classical professional accountability demands became supplemented with intensified political/bureaucratic accountability demands. Resources for education, research and ministry support activities are allocated to the universities through separate channels. Over time, resource allocation has become increasingly performance based. Resources for education have been linked to the number of students passing exams since the 1980s. Since 2009, this has been supplemented by the granting of extra resources to universities if students accomplish their study programs in due time. The allocation of basic resources for research among the universities has mostly been based on historical traditions, but since 2010 a performancebased element has been added, allocating portions of the basic resources according to the universities' ability to generate educational resources, produce $\mathrm{PhDs}$ and attract competition-based research resources, and according to their volume of research production. A bibliometric indicator has been developed upon inspiration from Norway.

Since 2000, a political/bureaucratic accountability mechanism in the form of development contracts between the ministry and the universities has been part of the governance regime. The aim of the contract regime is to make universities responsive to political goals. Contracts are followed up by documentation of results but have not been linked to resource allocation.

Accreditation has been introduced as another important accountability mechanism. In 2007, an accreditation institution at arm's length from the ministry was established and tasked with taking all study programs, new as well as existing, through accreditation. Hereby, the rather soft, compliance-based evaluation approach used during a period in the 1990s was changed to a more deterrence-oriented approach. This was experienced by academics as a sign of mistrust. Currently, the system is again being transformed, moving from focusing on educational programs to prioritising the quality-assurance systems of higher education institutions (HEls). Accreditation is a hybrid accountability mechanism. Accreditation criteria, including educational quality, relevance and quality assurance and management, have been decided politically by law but are enacted by panels consisting of peers, quality assurance experts and labour market representatives, as well as students.

Educational relevance and employability have in recent years become important accountability dimensions. Recently, a reform has been introduced according to which educational programs scoring badly on employability will be downsized. Further, a national database for higher education is being developed with the aim of increasing transparency in educational performance.

Managerial accountability has been strengthened in the wake of the governance and leadership reform introduced in 2003. The reform introduced university boards with an external majority and an external chairperson. Moreover, whereas leaders at all levels (department heads, deans and vice chancellors) prior to the reform were elected on a bottom-up basis, they are now appointed on a top-down basis. In addition, the role of collegial councils was changed to an advisory role. Moreover, the reform increased the formal autonomy of universities, giving them, for example, more influence on human resource policies, including establishing salaries. All in all, internal hierarchical accountability relations have been markedly strengthened. In some universities, departmental peer-review-based evaluation procedures have been introduced as a management tool.

Appointed leaders seem to take top-down-implemented accountability demands seriously. In this way, managerial accountability enables other forms of accountability. In particular, the political/bureaucratic accountability mechanisms linked to the different streams of performance-based funding have been implemented at all organisational levels. The increased pressure on academics to attract external funding from research councils and the like links the strengthened managerial accountability to professional accountability conducted through peer review.

\subsection{Finland}

Pursuing a higher level of accountability has played a substantial role in shaping the contents of Finnish university policy over the past 20 years. From the vantage point of political/bureaucratic accountability mechanisms, emphasising accountability has been strongly related to the adoption of a performance-based funding model. After a long period of applying incremental, line-item budgeting procedures for funding, the government changed policy in the beginning of the 1990s, when it adopted a block grant (lump sum) allocation model. Some years later, a more output- and performance-driven funding model, with a special emphasis on 
master's and doctoral degree targets, was introduced. The new model became fully effective during 1998-2003. The new university legislation from 2010 kept the core duties of teaching and research unchanged, but increased the importance of societal interaction and broader impact. However, both the financial and governance systems of universities were changed, pushing universities to compete for international research funding and donations. Further, the new legislation emphasised the need to increase revenues from business ventures and collaboration with societal partners.

Throughout 2003-2015, the policy of the ministry has been to update the funding model every three to four years. This corresponds with the standard period of performance agreements between the ministry and universities, which are also used as accountability instruments. Performance agreements contain university-specific objectives, such as those related to institutional mission, as well as key development measures and target figures. Realisation is followed by the ministry. As a part of the updating process, new indicators have been introduced. Nevertheless, updates have been quite moderate, aimed at providing stability and offering a sense of predictability for universities. The most important indicators have been accumulation of study credits and the number of degrees granted as well as throughput rates (education), amount of external competitive research funding gained, publications/bibliometrics (partly following the model developed in Norway) and number of doctoral degrees granted (research). Since 2013, the share of performance-based funding from the core state funding has amounted to $75 \%$, making the Finnish university funding system one of most performance-driven systems in the world (de Boer et al. 2015).

Finland has no accreditation system. External quality assurance procedures, established in 2005, are conducted by the national quality assurance agency (FINEEC, previously FINHEEC). These are not primarily for accountability purposes. They are intended first and foremost to serve quality enhancement. As such, they signal a higher level of trust regarding the self-regulation of universities.

At the same time, different forms of managerial accountability have been reinforced, especially over the past 10 years. This has been most evident in changes in remuneration schemes. In 2008, a new performancedriven salary system replaced the old system with salary categories and experience bonuses (age bonus) and a salary biannual evaluation of personal performance (teaching, research and other tasks). Salary level is based on a combination of how demanding the tasks are weighed against the level of individual performance in accomplishing those tasks. Moreover, a complete revision of university legislation in 2010 changed the legal status of universities from being part of the state administration to independent legal entities. The new status grants full employer rights. Accordingly, universities have become more autonomous in human resource management policies in general. Many of the universities have established full-time academic manager positions (most often deans) accompanied by management rights and accountability requirements.

Reforms of the university legislation have emphasised the social accountability of universities. The legislation prescribes that at universities acting as public corporations (now 12), the university board is to be composed of representatives of the tripartite (professors, other staff and students) and a minimum of $40 \%$ external members. The chairperson of the board must be an external member. Universities operating as private foundations (now two) are not subject to regulations regarding the number of external members. At the moment, their boards are composed of external members only. Moreover, several universities have appointed external members to their faculty boards. Calls for increased interaction with broader groups of external stakeholders have also become stronger in the past decade. These calls for societal accountability have stressed the need for researchers to make their expertise more accessible to the broader society.

Lastly, professional accountability in Finland has remained strong despite the recent reforms emphasising other forms of accountability. For instance, the Publication Forum (Julkaisufoorumi), a national rating and classification system of research publications, has been developed under the auspices of the Federation of Finnish Learned Societies. These assessments of the scientific quality and impact of publications have been utilised in the university funding model since 2015. In this way, peer review is used as a part of political/bureaucratic accountability relations. The use of bibliometrics as part of the performance evaluation system of the ministry has caused turmoil, even though the rating system itself has remained in the hands of the scientific community. Discussions continue regarding an increased focus on quantity over quality resulting from the use of bibliometrics. Moreover, research assessment exercises, which represent a common quality assurance method for internal quality assurance of universities, are based on peer review of scientific panels. Here, professional accountability and managerial accountability are interwoven. 


\subsection{Norway}

Accountability in Norwegian higher education, in its present form, originates from the 2003-2004 Quality Reform, which aimed at implementing Bologna, on the one hand, and devising a series of structural measures to foster overall effectiveness and accountability, on the other. The reform represented an overhaul of the entire system, including governance and funding, degree structure and teaching methods. Six key aspects of the reform are worth discussing.

Firstly, the establishment of an independent quality assurance agency (NOKUT) with the responsibility of accrediting new programs (excluding those at universities) and institutions (in the case of mergers or institutions wishing to become fully fledged universities). Accreditation was introduced along with systematic evaluations of institutional quality assurance systems. This system can be said to represent a new way to categorise the institutions where institutional autonomy is conditioned by the institutional status provided through the accreditation system. Only if an institution is accredited with the status of a fully fledged university is it given full rights or autonomy regarding the establishment and closing of study programs at all levels. All accreditation and evaluations are undertaken by NOKUT, assisted by extended peer review processes in which both academic staff and students participate, along with the professionals within the agency. Thus, in this respect the role of independent quality assurance agencies pertains to a mix, or hybrid, of different types of accountability, as described in Table 1.

Secondly, political/bureaucratic accountability has been intensified by the introduction of new types of performance-based mechanisms aimed at enhancing transparency and ensuring the achievement of efficiency gains. The funding formula for institutions was changed accordingly, with a performance component being introduced with respect to both students' productivity and, this on the basis of a bibliometric system composed of two levels of publications, research publications. In 2017, the funding system was adjusted. The new system incentivises institutions to become more entrepreneurial in securing external funding and further rewards both teaching productivity (measured by graduation rates) and research productivity.

Thirdly, accountability has been intensified since 2016 by the Norwegian government's use of an incremental approach to the implementation of performance agreements. The agreements are developed through dialogue between the ministry and each institution, the point of departure being the institution's own strategies. As of today, there are no mandatory indicators. From an accountability perspective, the agreements are thus hybrids combining political/bureaucratic accountability with managerial accountability. Funding is not currently linked to the agreements, but the ministry has signalled that this will be the case in the future.

Fourthly, the setting up of a national database for higher education has also been an important step towards improving accountability by providing information on system performance. Currently, the database contains information on staff, students and student mobility as well as financial data, and is mainly used by the ministry for planning, monitoring and budgetary purposes. It is accessible to everyone (open data) and frequently used by newspapers and other media.

Fifthly, changes in the governance and leadership structures of HEls, with strong representation by external actors at the board level, and the voluntary adoption of a system of appointed leaders at various levels (with substantial variations across institutions) have played an important role. Overall, autonomy has been enhanced and managerial accountability has been strengthened. More recently, regular programmatic evaluations, through both traditional peer reviews and student surveys, have become important components of the new accountability regime. A 2015 structural reform focusing on mergers between regional providers (concentration strategy) also emphasises quality and accountability.

Finally, as is the case in other countries, like Sweden, social aspects of accountability have been strengthened. Outreach has become a formal task for all HEls, including the flagship universities, and the research council has enacted a series of funding structures demanding the participation of external, nonacademic partners in the formal application process. Co-creation has also become an important component of the new post-NPM momentum facing the whole of the public sector, HEls included.

\subsection{Sweden}

In Sweden, starting from a political/bureaucratic perspective, the overall responsibility for higher education and research rests with the parliament and the government. They decide on the regulations that apply to the area. They also determine objectives, guidelines and the allocation of resources. The public-sector HEls are public agencies accountable to the Ministry of Education and Research. One exception is the Swedish University of 
Agricultural Sciences, which is accountable to the Ministry of Enterprise and Innovation.

As in the other countries, a national body for accreditation and quality assurance is in place, monitoring all higher education institutions. Sweden introduced a national quality assurance system in the early 1990 s. Initially, the system focused on accreditation and institutional audits. During 2001-2006, a comprehensive evaluation of all programs and subjects leading to a degree was conducted by a large number of peer review teams. In the latest round of reviews, completed in October 2014, excellence in education was also rewarded financially. A shift in focus could also be noted: whereas the previous models have scrutinised preconditions, processes and results, this system has basically targeted the output, as it materialised in the final thesis. This system was heavily debated. A new system introduced in 2016 consists of all the previous ingredients accreditation, programme and subject reviews and institutional audits.

As for research, performance-based funding was introduced as part of the direct state funding in 2009. Since then, $10 \%-20 \%$ of the allocation of funds has been based on (1) level of external funding and (2) publications. Moreover, this system has been discussed and criticised, in particular the bibliometric methodology and the weighting of various factors. Lately, the Swedish Higher Education Authority has been assigned the task of developing a national research assessment framework, to be used also for the allocation of resources (Swedish Government 2016)

Moving to the managerial aspects of accountability, the Swedish government bill that established greater autonomy for HEls (Swedish Government 2010a) created further opportunities for university managers to transform their organisations. With the exception of requirements regarding a board and a president, universities are free to develop their own organisation. Still, decisions requiring qualified assessments must be taken by those with professional qualifications, and students have rights to representation when decisions are taken regarding education. HEls can choose their own career structures and categories of staff, with some exceptions. Further, education is regulated at a less detailed level. The government bill known as 'A Reformed Constitution' (Swedish Government 2010b) included amendments increasing the institutional autonomy, including a provision protecting freedom of research formerly found in the Higher Education Act.

At the institutional level, a number of HEls have initiated institutional evaluations of both education and research. They have various aims but typically include some kind of peer review. In the case of research evaluations, bibliometrics is also commonplace. The consequences of the evaluations, in terms of 'carrots and sticks', also vary, from a primarily 'shaming' strategy for those who underperform to financial rewards for those who excel (Karlsson et al. 2014). Furthermore, many HEls have introduced performance-based funding systems that rely on publication and citation data (Hammarfelt et al. 2016).

As for professional accountability, there are no signs of decline in its importance. On the contrary: the amount of time spent on various kinds of peer review (publications, research projects, doctoral defences, appointments etc.) seems to take an increasing amount of time (Langfeldt \& Kyvik 2010). The importance of collegial bodies is still emphasised. Their freedom to organise has increased, and a faculty board at every institution it is no longer required. This has occasioned a debate about whether collegiality is at stake (Ahlbäck Öberg et al. 2016).

Lastly, the social aspect of accountability is increasingly coming to the fore, especially in relation to funding opportunities and quality enhancement. Collaboration with the surrounding society has become an end in itself, to be demonstrated when applying for funds, academic posts etc. External stakeholders, such as employers, are involved as coproducers of knowledge and in the development of new programs.

\subsection{Comparison}

The country analysis has shown that there are both similarities and differences across the Nordic higher education sectors. In all countries, there are multiple accountability demands that challenge and put pressure on institutions. In the political/bureaucratic accountability relationship, performance-based funding systems have been developed and, over time, refined in all four of the Nordic countries. Finland in particular has gone a long way along this road, as $75 \%$ of the core state funding since 2013 has been performance based. In all the countries, this development has fostered debates about the way performance should be measured and whether the increased transparency in performance has increased competition at the national level.

Professional accountability mechanisms have gained further importance as new forms of evaluation have been introduced and as pressure on academics to attract external funding has increased. This is particularly the case with regard to the development of external accountability. Finally, social accountability has been put on the agenda in all countries. External stakeholders are increasingly invited to participate in the dialogue on the 
development of universities and educational programs and the coproduction of knowledge, and they are interested in doing so. Moreover, societal deliverables in the form of research impact and employability are increasingly expected, but these measures are institutionalised only to a limited extent. This is especially apparent when it comes to funding as opposed to concerns such as publication and degree accumulation.

Managerial accountability mechanisms in the internal hierarchy also seem to have been strengthened in all countries, but to different degrees. In Denmark, a groundbreaking leadership reform was introduced in 2003 that suspended the classical principle of collegiality, as former collegial decision bodies were converted into advisory bodies. Further, the reform introduced appointed leaders (department heads, deans and vice chancellors), whereas leaders were formerly elected. Finnish reforms have also aimed at strengthening the management capacity and made HEls more autonomous, for example in relation to recruitment and remuneration practices. In the two other Nordic countries, Norway and Sweden, changes in the managerial accountability mechanism seem to have been more gradual, implying that the classical principle of collegiality has faced fewer challenges.

In all countries, the strengthened accountability demands have gone hand in hand with increasing formal institutional autonomy. We view these developments as two sides of the same coin, as part and parcel of the new governance regimes. Further, the enhanced institutional autonomy seems to strengthen managerial accountability demands, as previous research has suggested (Schmidtlein \& Berdahl 2005; Stensaker 2014).

Having analysed the changes in accountability demands and mechanisms, we now turn to an analysis of how academics experience the changes in accountability demands.

\section{Experiences and consequences}

In this section, we analyse how academics experience the accountability demands by investigating how they experience accountability expectations, whether they see accountability demands as legitimate and how they assess the impact of accountability procedures. ${ }^{2}$ The analysis are done by using non-parametric mean rank comparisons. The differences between two or more countries are tested by using Kruskall Wallis $\mathrm{H}$-test and the pair vice differences are analysed by using Dunn-Bonferroni test.

\subsection{Academics experiences concerning accountability}

As shown in Table 3, academics experience expectations related to teaching and research performance from both managers and colleagues in a rather similar way. However, academics seem to experience slightly higher expectations for research performance - both from managers and colleagues - than for teaching performance. High research-performance expectations from one's academic peers are experienced almost identically across countries. This provides an interesting starting point for the analysis. It could imply that the collegial pressures (as expectations) and competition are dependent not on country-specific policies emphasising performance, but rather on the internal logics of the academic profession (Teichler et al. 2013).

The answer to the survey statement 'I experience a high level of expectations from my unit's manager regarding research performance' was found to be significantly different across countries. In Denmark, the experienced performance expectations seem to be higher to some extent than in other countries. Statistically, Finland differs from other countries. It seems that in Finland, managerial expectations for teaching are lower than in the other Nordic countries. The most remarkable differences are in the experienced expectations for research performance from the unit manager. The pair vice comparison indicates that Denmark's mean score (M $=3,6$ ) for agreeing with the survey statement is higher than that of other Nordic countries. Moreover, Finland's mean score $(M=3,4)$ is higher in terms of statistical significance than Sweden's $(M=3,2)$, which is the lowest among all countries. This may indicate that unit managers in Denmark and Finland are increasingly recruited externally, whereas unit managers in Norway and Sweden are mostly recruited internally regardless of whether they are appointed or elected.

Overall, it seems that in all countries the hierarchical accountability relation towards managers is

\footnotetext{
2 We use expectations about performance from unit managers as a proxy for the strength of the managerial regime as such, as we interpret the strength of this regime as a function of changed accountability demands related to both political/bureaucratic as well as managerial types of accountability.
} 
experienced as stronger compared to professional accountability towards academic colleagues. Especially in Denmark, unit managers' expectations for research performance are experienced as high. However, in Sweden, unlike in other countries, the professional accountability expectations seem to be more important than the managerial ones. It also seems that teaching has remained a stronger area of autonomy in Finland than in other Nordic countries.

Table 3: Academics' perceptions on accountability expectations by country

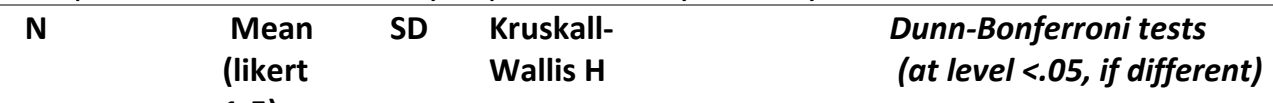

1-5)

Asymp.

Sig.

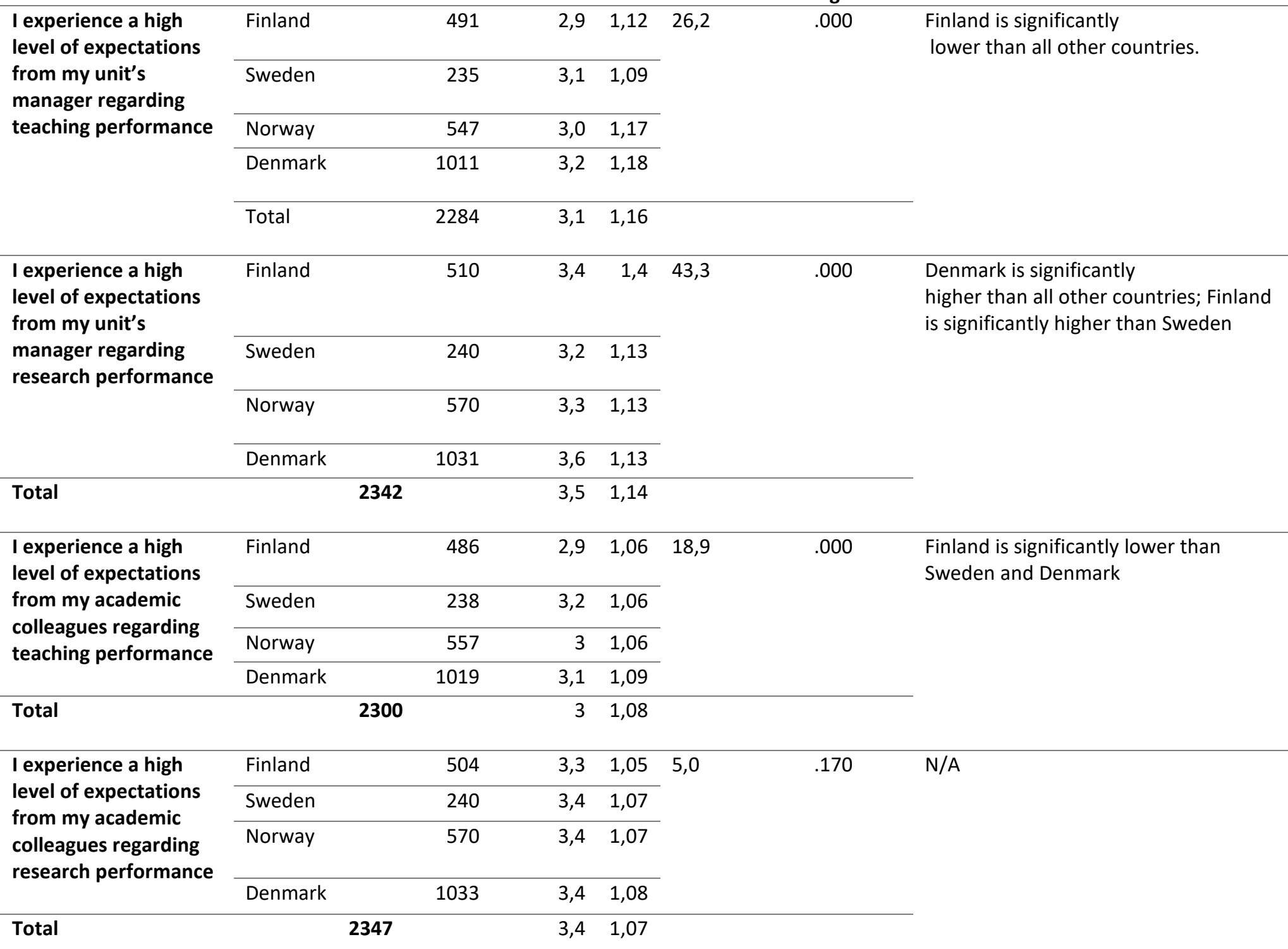

Scale: strongly disagree (1) - strongly agree (5)

4.2 Academics' views of accountability mechanisms: Meaningful or signs of mistrust?

Table 4 shows that on average, control and evaluation are perceived by Nordic academics as legitimate tasks, as this perception is stronger than regarding control and evaluation as signs of mistrust. However, there also seems to be a slight misalignment between the personal opinions regarding academic performance and measured academic performance per the statement 'Internal procedures for measuring academic performance are in 
accordance with my understanding of academic performance'. In all statements, there is a statistically significant relationship between the countries and respondents' perceptions. The post hoc test suggests that Denmark is again the country in which control, evaluation and measurement are experienced most negatively. There is a striking difference between Denmark and other Nordic countries with respect to perceiving measurement as a sign of mistrust. Compared to academics in other Nordic countries, particularly Finland $(2,6)$ but also Sweden $(2,7)$, Danish academics have stronger perceptions of measurement as a sign of mistrust $(3,3)$.

Table 4: Academics perceptions on accountability mechanisms by country

\begin{tabular}{|c|c|c|c|c|c|c|c|}
\hline & & $\mathbf{N}$ & $\begin{array}{l}\text { Mean } \\
\text { (likert } \\
1-5)\end{array}$ & SD & $\begin{array}{l}\text { Kruskall- } \\
\text { Wallis H }\end{array}$ & $\begin{array}{l}\text { Asymp. } \\
\text { Sig. }\end{array}$ & $\begin{array}{l}\text { Dunn-Bonferroni tests } \\
\text { (at level <.05) }\end{array}$ \\
\hline \multirow{5}{*}{$\begin{array}{l}\text { Control and evaluation of } \\
\text { my work is a legitimate } \\
\text { task }\end{array}$} & Finland & 491 & 3,4 & 1,06 & \multirow{5}{*}{13,7} & \multirow[t]{5}{*}{.003} & \multirow{5}{*}{$\begin{array}{c}\text { Denmark is } \\
\text { significantly lower than } \\
\text { Norway and Sweden }\end{array}$} \\
\hline & & 243 & & 1,07 & & & \\
\hline & Norway & 577 & 3,4 & 1,03 & & & \\
\hline & Denmark & 1071 & 3,3 & 1,12 & & & \\
\hline & Total & 2382 & 3,3 & 1,08 & & & \\
\hline \multirow{5}{*}{$\begin{array}{l}\text { Internal procedures for } \\
\text { measuring academic } \\
\text { performance are in } \\
\text { accordance with my } \\
\text { understanding of } \\
\text { academic performance }\end{array}$} & Finland & 487 & 2,6 & 1,15 & \multirow[t]{5}{*}{16,8} & \multirow[t]{5}{*}{.002} & \multirow{5}{*}{$\begin{array}{l}\text { Denmark is } \\
\text { significantly lower than } \\
\text { Finland and Norway }\end{array}$} \\
\hline & Sweden & 222 & 2,6 & 1,16 & & & \\
\hline & Norway & 519 & 2,6 & 1,11 & & & \\
\hline & Denmark & 1021 & 2,4 & 1,12 & & & \\
\hline & Total & 2249 & 2,4 & 1,16 & & & \\
\hline \multirow{5}{*}{$\begin{array}{l}\text { In my opinion } \\
\text { performance } \\
\text { measurements are signs } \\
\text { of mistrust }\end{array}$} & Finland & 524 & 2,6 & 1,20 & \multirow[t]{5}{*}{1019,4} & \multirow[t]{5}{*}{.000} & \multirow{5}{*}{$\begin{array}{l}\text { Denmark is } \\
\text { significantly higher } \\
\text { than all other } \\
\text { countries; Finland and } \\
\text { Sweden are } \\
\text { significantly lower than } \\
\text { Norway }\end{array}$} \\
\hline & Sweden & 242 & 2,7 & 1,20 & & & \\
\hline & Norway & 573 & 3,0 & 1,30 & & & \\
\hline & Denmark & 1068 & 3,3 & 1,29 & & & \\
\hline & Total & 2407 & 3,0 & 1,29 & & & \\
\hline
\end{tabular}

Scale: strongly disagree (1) - strongly agree (5)

\subsection{Academics' evaluation of consequences of accountability mechanisms}

Table 5 shows that academics from all countries are quite pessimistic about the positive impacts of performance measurement, with respect to both performance and the work atmosphere, despite the fact that they tend to consider measurement and evaluation fairly legitimate activities. This observation holds true for both research and teaching tasks. The country of respondents was found to have a statistically significant effect on all statements concerning the impacts of measurement. Here, the same pattern is observable: according to the pair vice comparison, Denmark is the country that most differs from the other three countries and the differences are higher in research than in teaching. Especially in the perceptions regarding the impacts of research performance measurement on the work atmosphere, the Danish $(M=1,9)$ mean score is significantly lower, and the Finnish mean score $(M=2,2)$ lower, than the Swedish mean score $(M=2,5)$.

Table 5: Academics' views on impacts of accountability mechanisms by country 


\begin{tabular}{|c|c|c|c|c|c|c|c|}
\hline & & $\mathbf{N}$ & $\begin{array}{l}\text { Mean } \\
\text { (likert } \\
1-5 \text { ) }\end{array}$ & SD & $\begin{array}{l}\text { Kruskall- } \\
\text { Wallis H }\end{array}$ & $\begin{array}{l}\text { Asymp. } \\
\text { Sig. }\end{array}$ & $\begin{array}{l}\text { Dunn-Bonferroni tests } \\
\text { (at level <.05) }\end{array}$ \\
\hline \multirow[t]{5}{*}{$\begin{array}{l}\text { Measurements increase my } \\
\text { performance in teaching }\end{array}$} & Finland & 503 & 2,3 & 1,17 & \multirow[t]{5}{*}{21,2} & \multirow[t]{5}{*}{.000} & \multirow{5}{*}{$\begin{array}{c}\text { Denmark is significantly } \\
\text { lower than Norway and } \\
\text { Sweden }\end{array}$} \\
\hline & Sweden & 233 & 2,4 & 1,18 & & & \\
\hline & Norway & 555 & 2,4 & 1,20 & & & \\
\hline & Denmark & 1066 & 2,1 & 1,13 & & & \\
\hline & Total & 2362 & 2,2 & 1,17 & & & \\
\hline \multirow{5}{*}{$\begin{array}{l}\text { Measurements increase my } \\
\text { performance in research }\end{array}$} & Finland & 523 & 2,6 & 1,26 & \multirow[t]{5}{*}{52,8} & \multirow[t]{5}{*}{.000} & \multirow{5}{*}{$\begin{array}{c}\text { Denmark is significantly } \\
\text { lower than all other } \\
\text { countries }\end{array}$} \\
\hline & Sweden & 242 & 2,6 & 1,25 & & & \\
\hline & Norway & 573 & 2,6 & 1,26 & & & \\
\hline & Denmark & 1079 & 2,2 & 1,20 & & & \\
\hline & Total & 2414 & 2,4 & 1,24 & & & \\
\hline \multirow{5}{*}{$\begin{array}{l}\text { Teaching performance } \\
\text { measurements have a } \\
\text { positive impact on the } \\
\text { atmosphere surrounding } \\
\text { academic work }\end{array}$} & Finland & 515 & 2,1 & 1,07 & \multirow[t]{5}{*}{40,6} & \multirow[t]{5}{*}{.000} & \multirow{5}{*}{$\begin{array}{l}\text { Denmark is lower than } \\
\text { Norway and Sweden; } \\
\text { Finland is significantly } \\
\text { lower than Sweden }\end{array}$} \\
\hline & Sweden & 237 & 2,4 & 1,20 & & & \\
\hline & Norway & 562 & 2,2 & 1,15 & & & \\
\hline & Denmark & 1077 & 2,0 & 1,10 & & & \\
\hline & Total & 2391 & 2,1 & 1,13 & & & \\
\hline \multirow{5}{*}{$\begin{array}{l}\text { Research performance } \\
\text { measurements have a } \\
\text { positive impact on the } \\
\text { atmosphere surrounding } \\
\text { academic work }\end{array}$} & Finland & 530 & 2,2 & 1,14 & \multirow[t]{5}{*}{72,5} & \multirow[t]{5}{*}{.000} & \multirow{5}{*}{$\begin{array}{l}\text { Denmark is significantly } \\
\text { lower than all other } \\
\text { countries; Finland is } \\
\text { significantly lower than } \\
\text { Sweden }\end{array}$} \\
\hline & Sweden & 242 & 2,5 & 1,31 & & & \\
\hline & Norway & 573 & 2,3 & 1,20 & & & \\
\hline & Denmark & 1090 & 1,9 & 1,11 & & & \\
\hline & Total & 2435 & 2,1 & 1,18 & & & \\
\hline \multirow{5}{*}{$\begin{array}{l}\text { Control and evaluation of } \\
\text { my work has a positive } \\
\text { impact on my teaching } \\
\text { performance }\end{array}$} & Finland & 494 & 2,5 & 1,10 & \multirow[t]{5}{*}{34,9} & \multirow[t]{5}{*}{.000} & \multirow{5}{*}{$\begin{array}{c}\text { Denmark is significantly } \\
\text { lower than all other } \\
\text { countries }\end{array}$} \\
\hline & Sweden & 236 & 2,7 & 1,20 & & & \\
\hline & Norway & 545 & 2,6 & 1,10 & & & \\
\hline & Denmark & 1039 & 2,4 & 1,13 & & & \\
\hline & Total & 2165 & 2,5 & 1,14 & & & \\
\hline \multirow{5}{*}{$\begin{array}{l}\text { Control and evaluation of } \\
\text { my work has a positive } \\
\text { impact on my research } \\
\text { performance }\end{array}$} & Finland & 509 & 2,6 & 1,14 & \multirow[t]{5}{*}{50,0} & \multirow[t]{5}{*}{.000} & \multirow{5}{*}{$\begin{array}{c}\text { Denmark is significantly } \\
\text { lower than all other } \\
\text { countries }\end{array}$} \\
\hline & Sweden & 238 & 2,6 & 1,22 & & & \\
\hline & Norway & 554 & 2,6 & 1,15 & & & \\
\hline & Denmark & 1047 & 2,3 & 1,14 & & & \\
\hline & Total & 2348 & 2,4 & 1,17 & & & \\
\hline
\end{tabular}

Scale: strongly disagree (1) - strongly agree (5) 


\section{Discussion and conclusion}

In this article, we have investigated the development of accountability demands in the university sectors in the Nordic countries and how academics experience and evaluate accountability mechanisms. Building on a typology of accountability types, we expected the first part of the analysis to reveal strengthened external political/bureaucratic accountability demands, strengthened internal managerial accountability mechanisms and, as a result, challenged or squeezed professional accountability mechanisms.

The analysis has shown that the strengthening of political/bureaucratic accountability demands has indeed taken place in all the four Nordic countries, first and foremost through the development and refinement of performance-based funding systems related to both education and research. Whereas the social contract between universities and society was previously largely based on trust, relationships today are mostly contractual or instrumentalist in nature, thus reflecting ideas inspired by principal-agent theory (Massen 2014). Managerial accountability mechanisms have also been strengthened in all countries, but to different degrees and with different change dynamics. Denmark in particular, but also Finland, has reformed managerial accountability mechanisms through governance and leadership reforms representimg a rather radical break from the past. In Norway and Sweden, changes have been less forced, and change processes have developed more gradually. Further, social accountability has been put on the agenda; how to account for research impact and employability is intensively discussed in all countries.

As for professional accountability mechanisms and peer-based collegiality, which historically have been core values in the world of higher education (Olsen 2007), interesting variations were detected. On the one hand, external professional accountability mechanisms have been strengthened alongside political/bureaucratic as well as managerial accountability demands. This is especially the case with respect to research in the form of professional accountability, either through direct peer review evaluation or indirectly via the use of bibliometrics. On the other hand, internal professional accountability mechanisms seem to have lost importance overall, particularly in Denmark. In Sweden, formal collegial bodies are still in place in most universities and make the crucial decisions on core academic matters. However, it is also evident that professional accountability has become interwoven with both the political/bureaucratic and managerial aspects of accountability. The dynamics of peer review are changing. The latter is frequently used to legitimise decisions on funding, quality assurance, accreditation, hiring etc. What we find reflects the changing nature of the academic profession, which has become more professionalised, competitive in nature, uncertain, and perhaps less attractive (Kwiek 2018).

In the second part of the analysis, focusing on academics' experiences and the perceived effects of accountability mechanisms, we expected to uncover tensions between accountability demands and critical viewpoints on impacts. The data, which make an important empirical contribution to the existing literature on university dynamics in the Nordic countries, show that academics experience higher managerial than professional collegial accountability expectations. The differences are, however, small in Norway and Sweden but somewhat larger in relation to research in Finland and especially in Denmark. This seems to indicate that classical professional collegiality (Clark 1983) faces more challenges in Denmark, which could also be expected due to radical reforms. Overall, Danish academics are clearly more critical than their Nordic colleagues in their viewpoints on whether accountability mechanisms are meaningful. Only a rather small share of academics (around one-fifth or fewer) experience positive impacts on their own performance and on the atmosphere surrounding research and teaching activities. Swedish academics are somewhat more positive about such impacts, which is interesting in view of the fact that reforms there have, in comparison, been less dramatic.

All in all, the analysis has shown that although various accountability types may be interwoven, they are not always aligned and mutually supporting. Often, they stress different criteria related to different aspects of the compound reality in contemporary universities. Whereas accountability systems are negotiated at the stage of coming into existence, they are less so when enacted. Unsurprisingly, the analysis has also shown that there are value conflicts concerning how to measure and evaluate academic performance in a meaningful way. As a result, our study advances current debates on accountability in universities by closely linking the concept to shifts in governance regimes (macro level), on the one hand, and perceived effects (trust, micro level), on the other. Future studies, comparative or otherwise, could further illuminate the extent to which the observed trends hold true in the case of other university systems and world regions. Further, studies could include more qualitative approaches to how performance, as it relates for instance to expectations and measurement, plays out in various contexts, and they could compare academics' experiences with system analyses of performance 
trends and effects.

\section{References}

Aagaard, K. (2012). Reformbølgen tager form. In Aagaard, K. \& Mejlgaard, N. (Eds.), Dansk forskningspolitik efter årtusindskiftet (pp. 37-57). Aarhus: Aarhus Universitetsforlag.

Abbot, A. (1988). The system of professions: An essay on the division of expert labor. Chicago: University of Chicago Press.

Ahlbäck Öberg, S., \& Sundberg. E. (2016). Avkollegialiseringen av den svenska högskolan. In S. Ahlbäck Öberg, L. Bennich-Björkman, J. Hermansson, A. Jarstad, C. Karlsson, \& S. Widmalm (Eds.), Det hotade universitetet (pp. 45-69). Stockholm: Dialogos förlag.

de Boer, H., Jongbloed, B., Benneworth, P., Cremonini, L., Kolster, R., Kottmann, A., \& Vossensteyn, H. (2015). Performance-based funding and performance agreements in fourteen higher education systems. Enschede: Center for Higher Education Policy Studies.

Bovens, M. (2007). Analysing and assessing accountability: A conceptual framework. European Law Journal 13(4), 447-468.

Bovens, M., Schillemans, T., \& Goodin, R. E. (2014). Public accountability. In M. Bovens, R. E. Goodin, \& T. Schillemans (Eds.), The Oxford handbook of public accountability (pp. 1-20). Oxford: Oxford University Press.

Byrkeflot H., Christensen T., \& Lægreid P. (2013). The many faces of accountability: Comparing reforms in welfare, hospitals and migration. Scandinavian Political Studies 37(2), 171-195.

Christensen, T., \& Lægreid, P. (2011). The Ashgate research companion to new public management. Surrey: Ashgate.

Christensen, T., \& Lægreid P., Eds. (2017). The Routledge handbook to accountability and welfare state reforms in Europe. Oxon: Routledge.

Clark, B. R. (1983). The higher education system: Academic organization in cross-national perspective. Los Angeles: University of California Press.

Dubnick M. J. (2014). Accountability as a cultural keyword. In M. Bovens, R. E. Goodin, \& T. Schillemans (Eds.), The Oxford handbook of public accountability (pp. 23-38). Oxford: Oxford University Press.

Fägerlind, I., \& Strömqvist, G. (2004). Reforming higher education in the Nordic countries: Studies of change in Denmark, Finland, Iceland, Norway and Sweden. Paris: International Institute of Educational Planning, UNESCO.

Gailmard, S. (2014). Conceptual flavor of principal-agent theory. In M. Bovens, R. E. Goodin, \& T. Schillemans (Eds.), The Oxford handbook of public accountability (pp. 90-105). Oxford: Oxford University Press.

Gornitzka, Å., Stensaker, B., Smeby, J-C., \& De Boer, H. (2004). Contract arrangements in the Nordic countries: Solving the efficiency-effectiveness dilemma? Higher Education in Europe, 29, 87-101.

Hammarfelt, B., Nelhans, G., Eklund, P., \& Åström, F. (2016). The heterogeneous landscape of bibliometric indicators: Evaluating models for allocating resources at Swedish universities. Research Evaluation, 25(3), 292305.

Hood, C. (1991). A public management for all seasons? Public Administration, 69(1), 3-19. 
Huisman, J. (2018). Accountability in higher education: Different forms, functions and forums. In E. Hazelkorn, H. Coates, \& A. C. McCormick (Eds.), Research handbook on quality, performance and accountability in higher education (pp. 125-138). Cheltenham: Edward Elgar.

Jongbloed, B., Enders, J., \& Salerno, C. (2008). Higher education and its communities: Interconnections, interdependencies and a research agenda. Higher Education, 56(3), 303-324.

Karlsson, S., Fogelberg, K. Kettis, Å., Lindgren, S. Sandoff, M. \& Geschwind, L. (2014). Not just another evaluation: A comparative study of four educational quality projects at Swedish universities. Tertiary Education and Management, 20(3), 239-251.

Kwiek, M. (2018). Changing European Academics: A Comparative Study of Social Stratification, Work Patterns and Research Productivity. London: Routledge.

Langfeldt, L. \& Kyvik, S. (2010). Researchers as evaluators: Tasks, tensions and politics. Higher Education, 62(2), 199-212.

Maassen, P. (2014). A new social contract for higher education? In G. Goastellec \& F. Picard (Eds.), Higher Education in Societies (pp. 33-50). Rotterdam: SensePublishers.

Neave, G. (2002). The stakeholder perspective historically explored. In J. Enders \& O. Fulton (Eds.), Higher education in a globalising world: International trends and mutual observations: A festschrift in honour of Ulrich Teichler (pp. 17-37). Dordrecht: Springer.

Olsen, J. P. (2007). The institutional dynamics of the European university. In P. Maassen \& J. P. Olsen (Eds.), University dynamics and European integration (pp. 25-54). Dordrecht: Springer.

Olsen, J. P. (2017). Democratic accountability and the terms of political order. European Journal of Political Science Review, 9(4), 519-537.

Pfeffer, J., \& Salancik, G. R. (2003). The external control of organizations: A resource dependence perspective. Stanford, CA: Stanford Business Books.

Powell, W. W., \& DiMaggio, P. (1991). The new institutionalism in organizational analysis. Chicago: University of Chicago Press.

Ramirez, F. O. (2010). Accounting for excellence: Transforming universities into organizational actors. In V. Rust, L. Portnoi, \& S. Bagely (Eds.), Higher education, policy, and the global competition phenomenon (pp. 43-58). Basingstoke: Palgrave.

Schmidtlein, F., \& Berdahl, R. (2005). Autonomy and accountability: Who controls academe? In P. Altbach, R. Berdahl, \& P. Gumport (Eds.), American higher education in the twenty-first century: Social, political, and economic challenges (pp. 71-90). Baltimore: John Hopkins University Press.

Stensaker, B. (2014). Troublesome institutional autonomy: Governance and the distribution of authority in Norwegian universities. In M. Shattock (Ed.), International trends in university governance: Autonomy, selfgovernment and the distribution of authority (pp. 34-48). New York: Routledge.

Stensaker, B., \& Harvey, L., Eds. (2011). Accountability in higher education: Global perspectives on trust and power. Abingdon: Routledge.

Swedish Government (2010a). En akademi i tiden - ökad frihet för universitet och högskolor. Government Bill 2009/10:149. Available at http://www.regeringen.se/rattsdokument/proposition/2010/03/prop.-200910149/ 
Swedish Government (2010b). En reformerad grundlag. Government Bill 2009/10:80. Available at https://www.riksdagen.se/sv/dokument-lagar/dokument/proposition/en-reformerad-grundlag GX0380

Swedish Government (2016). Kunskap i samverkan - för samhällets utmaningar och stärkt konkurrenskraft. Prop. 2016/17:50. Available at http://www.regeringen.se/rattsdokument/proposition/2016/11/prop.$\underline{20161750 /}$

Teichler, U., Arimoto, A., \& Cummings, W. K. (2013). The changing academic profession: Major findings of a comparative survey. Dordrecht: Springer. 